JEL J 240

DOI: $10.31264 / 2545-093 X-2018-2(2)-250-260$
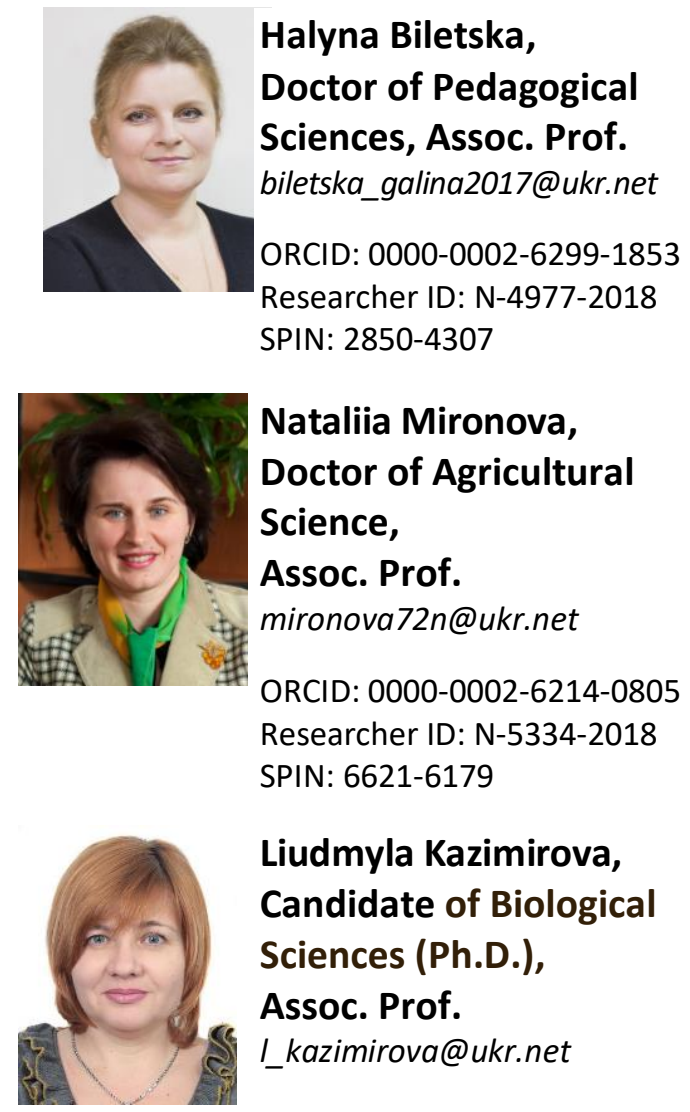

Nataliia Mironova, Doctor of Agricultural Science, Assoc. Prof. mironova72n@ukr.net

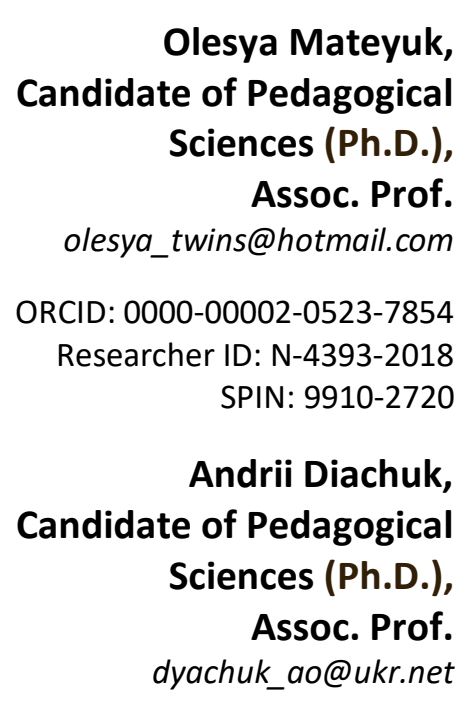

ORCID: 0000-0002-5974-7286

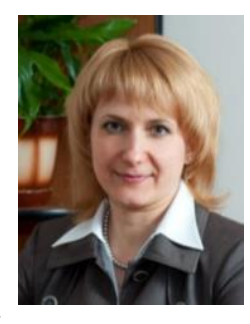

ORCID: 0000-0002-6214-0805 Researcher ID: N-5334-2018 SPIN: 6621-6179

Liudmyla Kazimirova,

Candidate of Biological

Sciences (Ph.D.),

Assoc. Prof.

I_kazimirova@ukr.net

ORCID: 0000-0001-5063-8764

Researcher ID: N-4762-2018

SPIN: 8395-7798
Researcher ID: N-4749-2018
SPIN: 8222-7949

\title{
EVALUATION OF EDUCATIONAL AND METHODICAL SUPPORT IN NATURAL SCIENCE TRAINING OF FUTURE ECOLOGISTS
}

\author{
EKSPERTYZA EDUKACYJNO-METODYCZNEGO ZABEZPIECZENIA \\ PRZYRODNICZO-NAUKOWEGO KSZTAŁCENIA EKOLOGÓW \\ ЭКСПЕРТИЗА УЧЕБНО-МЕТОДИЧЕСКОГО ОБЕСПЕЧЕНИЯ \\ ЕСТЕСТВЕННОНАУЧНОЙ ПОДГОТОВКИ БУДУЩИХ ЭКОЛОГОВ
}

\begin{abstract}
The article has been dedicated to the actual problem - an increase of efficiency of H. Biletska, N. Mironova, L. Kazimirova, O. Mateyuk, A. Diachuk


natural science training of future ecologists as a result of improvement the teaching and methodological materials. The aim of the study consists in evaluating quality of educational and methodological support of natural science training of future ecologists and to prove appropriateness of the outlined requirements for selecting the content of natural science training. For analytical evaluation the method of expert evaluations (surveys) was used. The work programs and e-courses of natural sciences in Modular object-oriented dynamic learning environment have been examined. To the evaluation teachers of natural sciences from the universities of Ukraine have been involved who have been training ecologists. To determine their competence and processing the survey results, the methods of mathematical statistics have been used.

It has been determined that the overall level of quality of the work programs of natural sciences on a five point scale is 4,39, e-courses-4,35. It has been found that the most significant indicators in the evaluation of the work programs are: the availability of the educational material in the content of the discipline that demonstrates the importance of natural sciences in the professional ecological activities; appropriateness of the discipline of educational professional program of preparation of bachelor specialty "Ecology"; modular structured educational material. During the evaluation of electronic courses the greatest importance have the following indicators: completeness and quality of diagnostic tools; electronic course content; the quality of informational teaching methodological materials. Since the indicators of the quality of educational and methodological materials have been selected on the basis of the set out in the study requirements for the content of natural science training of future ecologists, the importance of weight coefficients confirm the feasibility of the theoretical statements defined in the study about the selection of the content and structure of teaching material.

Keywords: professional ecological education, natural science training, support of teaching materials.

\section{Streszczenie}

Artykul jest poświęcony aktualnemu problemowi - podwyższeniu skuteczności przyrodniczo-naukowego kształcenia przyszłych ekologów $w$ wyniku udoskonalenia edukacyjno-metodycznego zabezpieczenia. Cel badania polega na ocenie jakości edukacyjno-metodycznego zabezpieczenia przyrodniczo-naukowego kształcenia przyszłych ekologów oraz potwierdzenie stosowności wyodrębnionych wymagań do odebrania treści przyrodniczo-naukowego kształcenia. Dla przeprowadzenia badania została wykorzystana metoda oceny ekspertyzy analitycznej (ankieta). Ekspertyzie podlegaty robocze programy oraz kursy elektroniczne przedmiotów przyrodniczonaukowych $w$ modułowym obiekt-orientowanym dynamicznym środowisku nauczania. Do przeprowadzania ekspertyzy zostali zaangażowani wykładowcy dyscyplin przyrodniczo-naukowych instytucji szkolnictwa wyższego w Ukrainie, które przygotowuja ekologów. W celu ustalenia ich kompetencji oraz opracowania wyników badania byty wykorzystane metody statystyki matematycznej.

Zostało ustalono, że ogólny poziom roboczych programów dyscyplin przyrodniczonaukowych na postawie skali 5-stopniowej wynosi 4,39, kursów on-line - 4,35. Ustalono także, że najważniejsze kryteria pod czas oceny programów roboczych sa następujace: dostępność $w$ treści przedmiotu materiału edukacyjnego, ukazującego znaczenie nauk przyrodniczych $w$ zawodowej ekologicznej działalności; zgodność treści

H. Biletska, N. Mironova, L. Kazimirova, O. Mateyuk, A. Diachuk 
dyscypliny edukacyjnej $z$ programem edukacyjno-zawodowym studiów i stopnia kierunek "Ekologia"; strukturyzacja modułowa materiałów edukacyjnych. Przy ocenie kursów on-line najważniejsze sa takie elementy: wyczerpujacy charakter oraz jakość diagnostyki; treść kursu on-line; jakość informacyjnych edukacyjno-metodycznych materiałów. Ponieważ wskaźniki jakości edukacyjno-metodycznego zabezpieczenia wybrane zostały $z$ uwzględnieniem wyznaczonych $w$ badaniu wymóg do treści przyrodniczo-naukowego przygotowania przyszłych ekologów, znaczenie współczynnika ważności potwierdzaja stosowność wyznaczonych $w$ badaniu teoretycznych pozycji co do odbioru treści oraz strukturyzacji materiatu edukacyjnego.

Kluczowe wyrazy: edukacja zawodowa ekologiczna, przyrodniczo-naukowe przygotowanie, ekspertyza edukacyjno-metodycznego zabezpieczenia.

\title{
Аннотация
}

Статья посвящена актуальной проблеме - повышению эффективности естественнонаучной подготовки будущих экологов в результате усовершенствования учебно-методического обеспечения. Цель исследования заключалась в оценке качества учебно-методического обеспечения естественнонаучной подготовки будущих экологов и подтверждении целесообразности сформулированных требований $\kappa$ отбору содержания естественнонаучной подготовки. Для экспертизы использовался метод аналитической экспертной оченки (анкетирование). Экспертизе поддавались рабочие программы и электронные курсы естественнонаучных дисциплин в модульной объектно-ориентированной динамичной среде обучения. К экспертизе были привлечены преподаватели естественнонаучных дисциплин высших учебных заведений Украины, которые осущуествляют подготовку экологов. Для определения их компетентности и обработки результатов анкетирования использовались методы математической статистики.

Определено, что общий уровень качества рабочих программ естественнонаучных дисциплин по пятибалльной шкале составляет 4,39, электронных курсов - 4,35. Выяснено, что важнейшими показателями при оценке рабочих программ являются: наличие в содержании дисциплины учебного материала, который демонстрирует значение естественных наук в профессиональной экологической деятельности; соответствие содержания учебной дисциплины образовательно-профессиональной программе подготовки бакалавров специильности “Экология”; модульное структурирование учебного материала. При оценке электронных курсов наибольшую значимость имеют следуюшие показатели: полнота и качество средств диагностики; содержание электронного курса; качество информационных учебно-методических материалов. Поскольку показатели качества учебно-методического обеспечения выбраны с учетом определенных в исследовании требований к содержанию естественнонаучной подготовки будущих экологов, значения коэффициентов весомости подтверждают целесообразность теоретических положений по отбору содержания и структурирования учебного материала.

Ключевые слова: профессиональное экологическое образование, естественнонаучная подготовка, экспертиза учебно-методического обеспечения.

\author{
H. Biletska, N. Mironova, L. Kazimirova, O. Mateyuk, A. Diachuk


Statement of the problem in general outlook and its connection with important scientific and practical tasks. In higher professional environmental education the prominent place occupies the naturalistic training. It is the foundation for learning disciplines of professional and practical training and mastering future profession; it promotes the formation of nature-scientific worldview, which is an integral part of human culture; forms a system of methodological knowledge in the context of future career; provides the basis for scientific researches. The importance of natural science training for environmental experts is due to the fact that their work is directly related to the use of knowledge and skills in the field of natural sciences. That is why the problem of improving natural science training of future ecologists is rather topical.

Analysis of latest research where the solution of the problem was initiated. Various aspects of natural science training in higher education institutions have been covered in a number of researches. Researchers indicate that natural science training is the basis for mastering special disciplines and the profession (Kasiarum, 2011; Starostina, 2011 et al.), develops cognitive activity, forms the concept of scientific methodology and logic of modern studies (Antonets, 2010; Ponomareva, 2008 et al.), allows understanding the regularities of the world, forms a holistic natural and scientific picture of the world and the worldview of a modern individual (Honcharenko, 1989; Stepaniuk, 2012 et al.), provides the individual with the opportunity to feel themselves part of nature (Aliieva, 2008 et al.).

However, in pedagogical researches, the problem of natural science training of future ecologists has not received a proper scientific understanding, in particular, the issues of developing requirements for the selection of the content of natural science training and structuring of educational material, and assessing the quality of teaching methodological material, considering these requirements remain insufficiently processed. In view of the said above, the evaluation of educational and methodological materials of natural science training of future ecologists in higher education institutions in order to determine its quality is extremely overdue task of educational researches.

Aims of paper. The aim of the study consists in evaluating quality of educational and methodological support of natural science training of future ecologists and to prove appropriateness of the outlined requirements for selecting the content of natural science training and educational material structuring. The aim is specified in the following objectives: 1) to determine indicators of quality of educational and methodological support of natural science training of future ecologists and indexes of their value; 2) to obtain proofs of representativeness of the outlined indicators and expediency of the outlined requirements for selecting and structuring the content of natural science training; 3) to determine the level of quality of educational and methodological support of natural science training of future ecologists.

Methodology. The research has been carried out at Ecology Department of Khmelnytskyi National University. In order to improve natural science training of future ecologists there have been developed work programs and e-courses of natural sciences ("Physics", "Chemistry with the Basics of Biogeochemistry", "Geology with the Basics of Geomorphology", "Hydrology", "Pedology", "Meteorology and Climatology", "Biology") in Modular object-oriented dynamic learning environment (Moodle).

The evaluation of educational and methodological support of natural science training of future ecologists included the implementation of the following steps: the determination of the goals of the evaluation, methods and terms of its implementation, selection of the experts and assessment of their competence; survey of the experts, analysis and processing of the received results.

At the first stage the goal of the evaluation has been determined, which was the evaluation of the quality of educational and methodological support of natural science training of future ecologists and confirmation of the representativeness of the singled indicators of quality. For the evaluation, the 
method of analytical expert assessment (survey) has been chosen. At this stage, as it the number of experts has been determined and the educational materials to be examined (work program and e-courses of natural sciences in Moodle) have been chosen.

In the second stage of the evaluation the expert committee of 24 members has been created. For the evaluation of educational and methodological support of natural sciences teachers at universities of Ukraine have been involved.

To determine the competence of experts the procedure proposed by B. Hershunskyi has been used (Hershunskyi, 1980). Experts answered the following questionnaire: scientific degree and rank; experience in the field of research problems; awareness of the investigated problem. Competence factor was calculated for each expert, using the formula (1) (Hershunskyi, 1980):

$$
\mathrm{K}_{\mathrm{e}}=\frac{\sum_{\mathrm{j}=1}^{3} \mathrm{X}_{\mathrm{ji}}}{\sum_{\mathrm{j}=1}^{3} \mathrm{X}_{\mathrm{imax}}},
$$

where $X_{j i}-$ value of $j$-th indicator for the $i$ th expert; $X_{\text {jmax }}-$ maximum rate of competency (2.4 points).

As a result of calculation it was found that the values of the coefficients of experts competence range from 0.71 to 1.00 and satisfy the requirements of $0.67<\mathrm{Re}<1$ (Hershunskyi, 1980). So the created group of experts is representative and all the experts can participate in the study.

The third stage involved the survey of experts. For the evaluation of the working programs of natural scientific disciplines, the following characteristics were selected:

- appropriateness of discipline to the current state of natural-scientific knowledge and modern ecological idea;

- compliance of the subjects contents with regulatory requirements (as currently the Standard of higher education in Ukraine for specialty "Ecology" is not approved during the expertise to match the content of subjects with regulatory requirements, experts used the educational and professional program of bachelors at the specified specialty in Khmelnytskyi National University);

- availability in the content of the discipline the interdisciplinary connections between natural sciences;

- availability in the content of the discipline, the educational material that demonstrates the importance of natural sciences in the professional activity of ecologists (professionally-directed learning material content);

- modular structuring of educational material.

For the examination of e-courses of natural sciences in Moodle, the following indicators were used:

- the content of e-course (appropriateness of the current state of scientific knowledge, availability, regularity and consistency of presentation, interdisciplinary connections between natural sciences, professional orientation to the training material);

- structure of the e-course (availability of all course resources: informational teaching materials, teaching materials for performance of different types of work, diagnostic tools, interactive means of communications, etc.);

- the quality of information teaching materials (amount of educational material, its scientific innovation and reliability, taking into account the current level of knowledge of the area, the presence of multimedia, video and audio-tracks);

- quality of the teaching materials for performance of various types of work (laboratory and practical work, independent work);

- completeness and quality of diagnostic tools (availability of tests for different types of control: input, topical, final, etc., validity and reliability of tests);

- the interactive possibility of e-course (availability of interactive communications that provide interaction of subjects of the education process);

- language and literary style of e-course (purity of language, its imagery, lack of borrowed Russian words etc.).

As defined parameters cannot be considered equal in significance, the first stage survey experts were asked to rank the quality

\section{H. Biletska, N. Mironova, L. Kazimirova, O. Mateyuk, A. Diachuk}


indicators of the support of teaching methods on their priority. Next to each index the coefficient of validity was determined by the formula (2) (Hershunskyi, 1980):

$$
\mathrm{K}_{\mathrm{B}}=\frac{\sum_{\mathrm{i}=1}^{\mathrm{n}} \mathrm{C}_{\mathrm{i}}}{\sum_{\mathrm{i}=1}^{\mathrm{n}} \mathrm{C}_{\max }},
$$

where $\mathrm{C}_{\mathrm{i}}$ - points of the 1-st index; $\mathrm{C}_{\max }-$ the maximum possible score (for work programs - 360, for electronic courses - 672).

The last stage of the evaluation interview suspected the direct evaluation of working programs and e-courses of natural sciences Evaluation has been carried out on a 5-point scale: unsatisfactory (1 point); Satisfactory ( 2 points); Good (3 points); Very good (4 points); Excellent (5 points). Processing of the results of experts survey was carried out by methods of mathematical statistics.

Exposition of main material of research with complete substantiation of obtained scientific results. As the result of the survey of experts the scores for each indicator have beenobtained and the significance of indicators quality and work programs and ecourses of natural sciences in Moodle have been determined (Table 1).

\section{Table 1. Points and weight ratios indicators of quality of educational and} methodological materials

\begin{tabular}{|c|c|c|c|}
\hline $\mathrm{N}$ & Indicator & Points & $\mathrm{K}_{\mathrm{B}}$ \\
\hline \multicolumn{4}{|c|}{ Working programs of natural sciences } \\
\hline 1 & $\begin{array}{l}\text { The compliance of the discipline content to the current state of } \\
\text { science and modern ecological knowledge representation }\end{array}$ & 69 & 0,19 \\
\hline 2 & $\begin{array}{l}\text { The appropriateness of the discipline content to the educational } \\
\text { professional program of the preparation of bachelors at the } \\
\text { specialty "Ecology" }\end{array}$ & 76 & 0,21 \\
\hline 3 & $\begin{array}{l}\text { The availability in the discipline content the interdisciplinary } \\
\text { connections between natural sciences }\end{array}$ & 61 & 0,17 \\
\hline 4 & $\begin{array}{l}\text { The availability in the discipline content the educational material } \\
\text { which demonstrates the importance of science in professional } \\
\text { environmental activities }\end{array}$ & 79 & 0,22 \\
\hline 5 & $\begin{array}{l}\text { Compliance with the requirement of modular structuring of } \\
\text { educational material }\end{array}$ & 75 & 0,21 \\
\hline \multicolumn{2}{|c|}{ Total: } & 360 & 1,00 \\
\hline \multicolumn{4}{|c|}{ Electronic courses of natural sciences in Moodle } \\
\hline 1 & The content of e-course & 126 & 0,19 \\
\hline 2 & The structure of e-course & 76 & 0,11 \\
\hline 3 & Quality of information teaching materials & 105 & 0,16 \\
\hline 4 & The quality of teaching materials for various types of work & 92 & 0,14 \\
\hline 5 & The completeness and quality of means of diagnostics of e-course & 132 & 0,20 \\
\hline 6 & Interactive e-course opportunities & 83 & 0,12 \\
\hline 7 & Language and literary style of e-course & 58 & 0,08 \\
\hline \multicolumn{2}{|c|}{ Total: } & 672 & 1,00 \\
\hline
\end{tabular}

Whereas, the indexes of quality of teaching methodological materials were selected considering the set out requirements for the content of natural science training of future ecologists, the value of coefficients confirm the feasibility of the theoretical statements determined in the study as defined in on selection of the content and structure of educational material.

Higher education in essence is professional, that is why compulsory is the requirement for the content of natural science training of future professional ecologists as we believe professionally aimed character, is

H. Biletska, N. Mironova, L. Kazimirova, O. Mateyuk, A. Diachuk 
study material should be selected and structured so that its absorption contributed to mastering of future profession and influenced the formation of professional competencies (Briukhanova, 2007). The indicator takes into account this requirement, the experts rated as the most significant.

The content of natural science training of future ecologists should also meet the actual and future needs of society and ensure that the objectives of professional environmental education, reflected in the regulations. The indicator reflecting this requirement in the selection of content, the experts rated as the second most significant

Another requirement for the formation of the content of natural science subjects training is the need to be submitted in the form of interconnected elements of the content. These elements in the structure of natural sciences are modules. An index that allows modular content structuring discipline, experts also rated as the second most significant.

Now science gets the importance of system building factor, which becomes a part of human culture (Starostina, 2011). Considering this, the content of natural sciences must meet current state of science knowledge and modern ecological concepts, to ensure the formation of a coherent natural-scientific world through the implementation of intersubject approach and synthesis of natural knowledge. The need to incorporate these requirements when selecting the content of natural scientific training laboratory scientists emphasize didactics Academy of Pedagogical Sciences of Ukraine (Vaskivska, 2015; Lypova, 2014; Trubacheva, 2016 etc.). The weights of indicators that reflect these requirements indicate the desirability of consideration when selecting the content of natural science training of future ecologists.

During the evaluation of e-courses of natural sciences the greatest importance, according to experts, are the following indicators: completeness and quality of diagnostic tools; electronic course content; information quality teaching materials. Fewer points were given to the following indicators: quality of teaching materials for different types of work; interactive electronic exchange capabilities; electronic structure of the course. High weight ratios indicators related to the content of courses and quality of information teaching materials, also shows the feasibility of the examined requirements for selecting the content of natural and scientific training of future ecologists and structuring of educational material.

At the final stage of processing the results of experts interviews there was calculated the points, which were received by the indicators of quality of working programs and e-courses of natural sciences in Moodle, taking into account certain weights coefficient. The level of quality of each indicator was calculated as the product of its arithmetic mean value $(\overline{\mathrm{X}})$ and importance factor $\left(K_{B}\right)$ (Table 2).

As a result of calculations it was found that the overall quality of the working programs of natural sciences is 4.39, e-courses in Moodle 4.35 .

The data presented in Table 2 show that during the evaluation of work programs the highest are the levels of indicators quality: the presence in the content of discipline training material that demonstrates the importance of science in environmental professional activity; the appropriateness of the discipline content to the educational - professional program of the preparation of bachelors at the specialty "Ecology"; compliance with a requirement of modular structuring of educational material. When evaluating the e-courses of natural sciences in Moodle the highest level of quality are typical for indicators quality: completeness and quality of diagnostic e-course; electronic course content; quality of information teaching materials.

When comparing the levels of quality indicators and weighting coefficients it was found that the highest scores were indicators that have been recognized by the experts as the most significant (Fig. 1 and Fig. 2).

Thus, as a result of the expertise there were obtained the evidences of representativeness of the assessed quality indicators of educational and methodological support of natural science training of future ecologists.

Conclusions. Analysis of the results of expert evaluation allowed us to draw the following conclusions:

\section{H. Biletska, N. Mironova, L. Kazimirova, O. Mateyuk, A. Diachuk


- the most influential figures in the evaluation of working programs are: the presence of a sense of discipline training material that demonstrates the importance of science in professional environmental activities (0.22); the appropriateness of the discipline content to the educational professional program of the preparation of bachelors at the specialty "Ecology" (0.21); modular structuring of educational material (0.21). During the evaluation of e-courses of natural sciences the greatest importance have the following indicators: completeness and quality of diagnostic products (0.20); electronic course content (0.19); quality of teaching materials for laboratory and practical work $(0,54)$; quality of information teaching materials (0.16). The importance of indicators evaluating the quality of teaching methodological materials justifies the expediency of singled theoretical principles for shaping the content of natural science training of future ecologists;

- the highest scores showed the indicators that have been recognized by experts as the most important. Thus, the indicators selected for examination are representative, and the results of peer review - are reliable;

- overall quality of educational and methodological support of natural science training of future ecologists is quite high. Working programs of natural sciences on a five-point scale assessment were rated 4.39 points, electronic courses $-4,35$ points.

Table 2. Results of processing the experts survey results with methods of mathematical statistics

\begin{tabular}{|c|c|c|c|c|}
\hline $\mathrm{N}$ & Indicator & $\mathrm{K}_{\mathrm{B}}$ & $\overline{\mathrm{X}}$ & $\begin{array}{l}\text { Level of } \\
\text { quality }\end{array}$ \\
\hline \multicolumn{5}{|c|}{ Working programs of natural sciences } \\
\hline 1 & $\begin{array}{l}\text { Compliance of the discipline content to the current state of } \\
\text { science and modern ecological knowledge representation }\end{array}$ & 0,19 & 4,17 & 0,79 \\
\hline 2 & $\begin{array}{l}\text { The appropriateness of the discipline content to the } \\
\text { educational professional program of the preparation of } \\
\text { bachelors at the specialty "Ecology" }\end{array}$ & 0,21 & 4,58 & 0,96 \\
\hline 3 & $\begin{array}{l}\text { The availability in the discipline content the interdisciplinary } \\
\text { connections between natural sciences }\end{array}$ & 0,17 & 4,04 & 0,69 \\
\hline 4 & $\begin{array}{l}\text { The availability in the discipline content the educational } \\
\text { material which demonstrates the importance of science in } \\
\text { professional environmental activities }\end{array}$ & 0,22 & 4,62 & 1,02 \\
\hline 5 & $\begin{array}{l}\text { Compliance with the requirement of modular structuring of } \\
\text { educational material }\end{array}$ & 0,21 & 4,42 & 0,93 \\
\hline \multicolumn{2}{|c|}{ Total: } & 1,00 & 21,83 & 4,39 \\
\hline \multicolumn{5}{|c|}{ Electronic courses of natural sciences in Moodle } \\
\hline 1 & The content of e-course & 0,11 & 4,38 & 0,48 \\
\hline 2 & The structure of e-course & 0,19 & 4,33 & 0,83 \\
\hline 3 & Quality of information teaching materials & 0,16 & 4,33 & 0,69 \\
\hline 4 & The quality of teaching materials for various types of work & 0,14 & 4,42 & 0,62 \\
\hline 5 & $\begin{array}{l}\text { The completeness and quality of means of diagnostics of e- } \\
\text { course }\end{array}$ & 0,20 & 4,50 & 0,90 \\
\hline 6 & Interactive e-course opportunities & 0,12 & 4,13 & 0,49 \\
\hline 7 & Language and literary style of e-course & 0,08 & 4,29 & 0,34 \\
\hline \multicolumn{2}{|c|}{ Total: } & 1,00 & 30,38 & 4,35 \\
\hline
\end{tabular}

H. Biletska, N. Mironova, L. Kazimirova, O. Mateyuk, A. Diachuk 


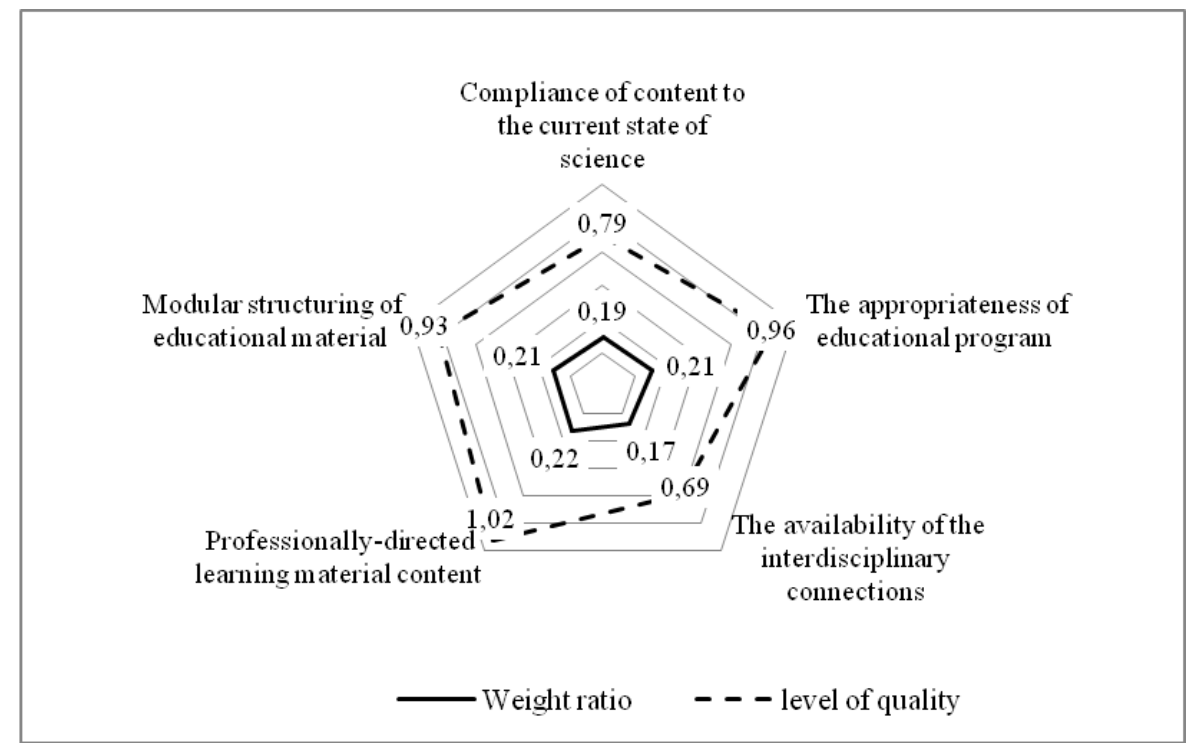

Figure 1. Chart comparing the weight ratios and levels of quality indicators in assessing the working programs

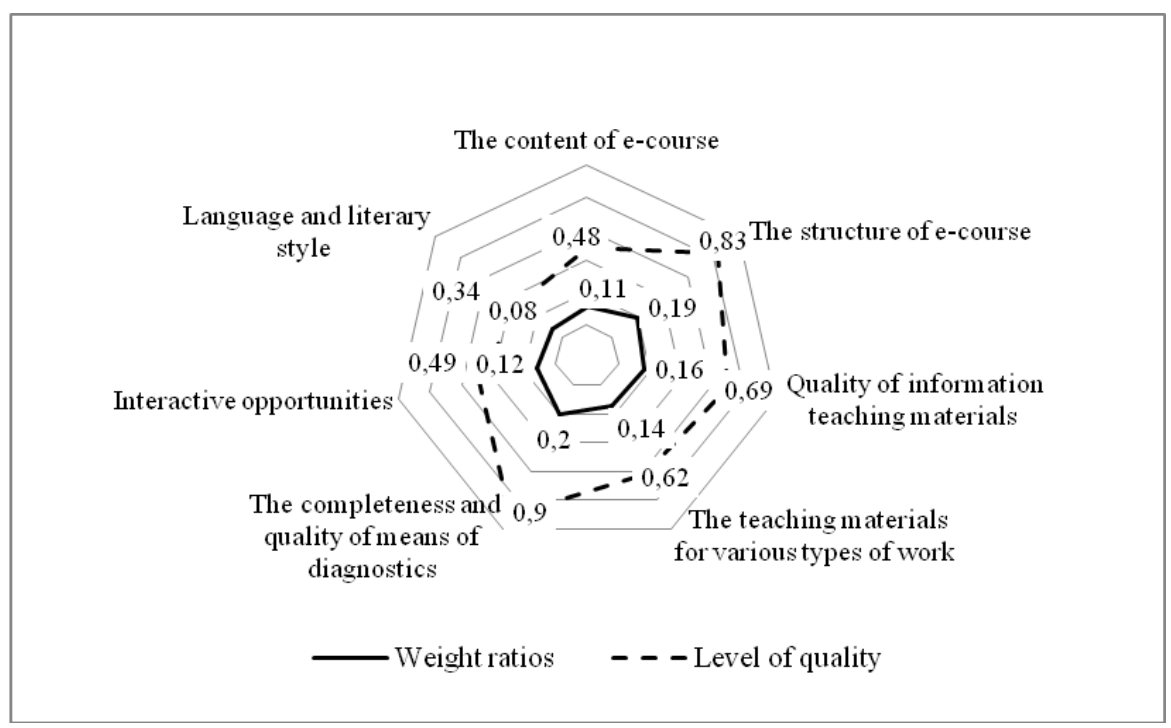

Figure 2. Chart comparing weight ratios and levels of quality indicators in assessing the e-courses

Perspectives for further scientific research we see in the theoretical foundation and the development of integrated special course that will provide the generalization and systematization of natural sciences, and creating innovative methods of natural science training.

\section{H. Biletska, N. Mironova, L. Kazimirova, O. Mateyuk, A. Diachuk}




\section{Bibliography:}

1. Алиева Н. 3. Постнеклассическое естественнонаучное образование : концептуальные и философские основания : монография / Н. З. Алиева. - Москва. : Издательство “Академия естествознания", 2008. - 512 с.

2. Антонець А. В. Організаційно-методична модель формування прогностичних умінь майбутніх менеджерів у процесі вивчення дисциплін природничо-наукового циклу / А. В. Антонець // Науковий часопис Національного педагогічного університету ім. М.П. Драгоманова (Серія "Педагогічні науки"). - 2010. - С. 9-14.

3. Брюханова Н. О. Зміст освіти : аспекти вивчення / Н. О. Брюханова // Проблеми інженернопедагогічної освіти. - 2007. - № 18/19. - С. 57-68.

4. Васьківська Г. Міжпредметність як необхідна умова модернізації змісту освіти / Галина Васьківська // Сучасні тенденції розвитку освіти і науки в інтердисциплінарному контексті : I Міжнар. наук.-практ. конф., 19-20 лист. 2015 р : матеріали конф. - Ченстохова - Ужгород Дрогобич, 2015. - С. 91-92.

5. Гершунский Б. С. Прогнозорование содержания обучения в технікумах : учеб.-метод. пособие / Б. С. Гершунський. - Москва : Высш. шк., 1980. - 144 с.

6. Гончаренко С. У. Методологические и теоретические основы формирования у учащихся средней школы естественнонаучной картины мира : автореф. дис. на соискание учен. степени д-ра пед. наук : спец. 13.00.01 “Общая педагогика и история педагогики”; 13.00.02 “Теория и методика обучения физики” / С. У. Гончаренко. - Киев, Киевский государственный политехнический институт имени Максима Горького, 1989. - 56 с.

7. Касярум С. О. Базові знання 3 природничо-наукових дисциплін як основа для професійної підготовки майбутніх фахівців інженерного профілю у вищій технічній школі / С. О. Касярум // Вісник Черкаського національного університету імені Богдана Хмельницького. - Випуск 165. Серія “Педагогічні науки”, 2011. - С. 141-144.

8. Липова Л.А. Генералізація як вищий рівень узагальнення природничих знань / Л.А. Липова // Дидактика : теорія і практика : зб. наук. праць. - 2014. - С. 29-35.

9. Пономарьова Г. Ф. Деякі завдання підвищення кваліфікації викладачів природничо-наукових дисциплін у педагогічному вищому навчальному закладі / Г. Ф. Пономарьова // Засоби навчальної та науково-дослідної роботи. - 2008. - № 28. - 88-95.

10. Старостина С. С. Естественнонаучное образование студентов гуманитарных направлений подготовки в условиях интеграции научного знания : дис. ... доктора пед. наук : 13.00 .02 / Старостина Светлана Ефимовна. - Чита, Забайкальский ГГПУ имени Н. Г. Чернышевского 2011. $472 \mathrm{c}$.

11. Степанюк А. В. Формування цілісних знань школярів про живу природу : монографія / А. В. Степанюк. - Тернопіль : Вектор, 2012. - 228 с.

12. Трубачева С. Е. Дидактичні особливості реалізації метапредметного підходу в умовах профільного навчання / С. Е. Трубачева, О. В. Чорноус // Дидактика : теорія і практика : зб. наук. праць, 2016. - С. 64-70.

\section{References:}

1. Alieva, N.Z. (2008), Postneklassicheskoe estestvennonauchnoe obrazovanie: kontseptualnye $i$ filosofskie osnovaniia [Post-nonclassical natural science education: conceptual and philosophical grounds], Izdatelstvo "Akademiia estestvoznaniia", Moskva, Russia.

2. Antonets, A.V. (2010), "Organizational and methodical model of forming predictive skills of future managers in the process of studying the disciplines of the natural sciences cycle", Naukovyi chasopys Natsionalnoho pedahohichnoho universytetu imeni M. P. Drahomanova (Seriia "Pedahohichni nauky”), pp. 9-14.

3. Briukhanova, N.O. (2007), "The content of education, aspects of study", Problemy inzhenernopedaghoghichnoi osvity, vol. 18/19, pp. 57-68.

4. Vaskivska, G.H. (2015), "Intergration of subjects as a prerequisite for modernization of educational content", Suchasni tendencii rozvytku osvity i nauky $v$ interdyscyplinarnomu konteksti [Modern trends in education and science in interdisciplinary context], Chenstokhova - Uzhghorod - Droghobych, Ukraine, pp. $91-92$.

\section{H. Biletska, N. Mironova, L. Kazimirova, O. Mateyuk, A. Diachuk


5. Hershunskii, B.S. (1980), Prognozorovanie soderzhaniia obucheniia v tekhnikumakh [Prediction of learning content in vocational schools], Vysshaia shkola, Moskva, Russia.

6. Goncharenko, S.U. (1989), Methodological and theoretical foundations for forming secondary school pupils' natural science picture of the world, Abstract of Ph.D. dissertation, Kievskii gosudarstvennyi politehnicheskii institut imeni Maksima Gorkogo, Kyiv, Ukraine.

7. Kasiarum, S.O. (2011), "Basic knowledge of natural sciences as the basis for professional training of future engineering specialists at a higher technical school", Visnyk Cherkaskoho natsionalnoho universytetu imeni Bohdana Khmelnytskoho. Seriia “Pedahohichni nauky”, vol. 165, pp. 141-144.

8. Lypova, L.A. (2014), "Generalization as a higher level of integration of natural knowledge", Dydaktyka: teoriia i praktyka, pp. 29-35.

9. Ponomarova, H.F. (2008), "Some tasks of professional development of natural sciences teachers in pedagogical higher educational institutions", Zasoby navchalnoi ta naukovo-doslidnoi roboty, vol. 28, pp. 8895.

10. Starostina, S.Ye. (2011), Natural scientific Education of students of humanitarian specialities Preparation in conditions of integration of scientific knowledge, Ph.D. Thesis, Zabaikalskii gosudarstvennyi humanitarno-pedagogicheskii universitet imeni N. G. Chernyshevskoho, Chita, Russia.

11. Stepaniuk, A.B. (2012), Formuvannia tsilisnykh znan shkoliariv pro zhyvu pryrodu [Forming holistic knowledge of schoolchildren about wildlife], Vektor, Ternopil, Ukraine.

12 Trubacheva, S.E. and Chornous. O.V. (2016), "Didactic features of implementation of metasubject approach in terms of Special Education”, Dydaktyka: teoriia i praktyka, vol. 4, pp. 64-70.

\author{
H. Biletska, N. Mironova, L. Kazimirova, O. Mateyuk, A. Diachuk
}

